\title{
MPRA
}

Munich Personal RePEc Archive

\section{A Panel Data Study of the Effects of Economic Freedom, Regulatory Quality, and Taxation on the Growth Rate of Per Capita Real GDP}

Cebula, Richard and Foley, Maggie

Jacksonville University, Jacksonville University

21 April 2011

Online at https://mpra.ub.uni-muenchen.de/54703/

MPRA Paper No. 54703, posted 25 Mar 2014 05:50 UTC 
Richard J. Cebula*

Walker/Wells Fargo Endowed Professor in Finance, Jacksonville University, Jacksonville, FL 32211-USA

Maggie Foley

Department of Finance, Jacksonville University, Jacksonville, FL 32211-USA

*Corresponding Author

E-mail: dr.richardcebula@gmail.com

\title{
A Panel Data Study of the Effects of Economic Freedom, Regulatory Quality, and Taxation on the Growth Rate of Per Capita Real GDP
}

\begin{abstract}
This study empirically investigates three hypotheses. The first is that higher levels of economic freedom in an economy promote a higher growth rate of economic activity and hence yield a higher growth rate of per capita real GDP in that economy. The second hypothesis is that higher quality government regulation leads to a more efficient economic system, in large part by interfering less with market functioning and in part by not adding unnecessarily to the cost of conducting business in the marketplace, and thereby leads to a higher per capita real GDP growth rate. The third hypothesis is that the higher the taxation level/burden relative to GDP in an economy, the lower the growth rate of private sector spending and hence the lower the growth rate of per capita real GDP in that economy. Using a panel dataset for OECD nations over the 2003 through 2006 period, fixed effects PLS estimations find compelling evidence in support of all three of these hypotheses.
\end{abstract}

Keywords - Economic Growth, Economic Freedom, High Quality Regulation, Tax Burden JEL Classification Code - O43, O47, P12, P14, L53, H22, H24

\section{1.- Introduction}

Over the past quarter of a century, numerous studies have been conducted expressly to investigate the impact of economic freedom on economic growth. Most of these empirical studies find that there exists a positive and statistically significant impact of economic freedom, especially a measure of overall economic freedom, on the rate of economic growth (Ali, 1997; Ali and Crain, 2001; Bennett and Vedder, 2013; Cebula, 2011; Clark and Lawson, 2008; Cole, 2003; Dawson, 1998, 2003; De Haan and Strum, 2000; Goldsmith, 1995; Gwartney, Holcombe, and Lawson, 2006; Hall, 2013; Hall, Sobel, and Crowley, 2010; Heckelman, 2000; Heckelman and Stroup, 2000; Nissan and Niroomand, 2008; Norton, 1998). This common finding is 
predicated presumably upon the ability of increased economic freedom to elevate the growth rate of economic activity through incentives to work, invest, save, hire/dismiss, make market-based business decisions, and engage in risk-reward economic behaviors in a market-based economy. ${ }^{1}$

This study seeks to extend this literature by: (1) deleting from the overall measure of economic freedom generated by the Heritage Foundation three "problematic" measures of economic freedom, one which introduces extensive multi-collinearity (fiscal freedom) into the system and two whose composition not only predominantly consists of some form of market regulation per se (business freedom and financial freedom) but also introduces significant multicollinearity into the model; and (2) replacing these three economic freedom measures with (a) a more direct and much more comprehensive measure of the total burden of government taxation and (b) an overall measure of "regulatory quality" per se, respectively.

Accordingly, in the pursuit of providing more dependable and useful insight into the economic growth-economic freedom/tax burden/government regulation linkage, this study empirically investigates three hypotheses. The first hypothesis is that higher levels of economic freedom in an economy promote a higher growth rate of economic activity and hence yield a higher growth rate of per capita real GDP in that economy, ceteris paribus. The second hypothesis is that higher quality government regulation leads to a more efficient economic system, in large part by interfering less with market functioning and in part by not adding unnecessarily to the cost of conducting business in the marketplace, and thereby leads to a higher per capita real GDP growth rate, ceteris paribus. The third hypothesis, which appears especially relevant in view of both recent policies and current plans in the U.S., France, and other OECD

\footnotetext{
${ }^{1}$ The emphasis in this study parallels in principle the alternative perspective focusing on economic freedom and the per capita real income level, such as that in Wiseman and Young (2011) for states within the U.S, and certain other studies, including Grubel (1997), Islam (1996), and Nissan and Niroomand (2008).
} 
nations that involve raising personal and/or corporate income tax rates in recent years, is that the higher the taxation level/burden relative to GDP in an economy, the lower the growth rate of private sector spending and hence the lower the growth rate of per capita real GDP in that economy, ceteris paribus.

To provide a broad and diverse context for the empirical analysis of these hypotheses, we focus on the 30 member nations of the OECD in the pre-Great Recession period from 2003 through $2006 .^{2}$ Within this perspective, the present study investigates whether international (purchasing-power-parity adjusted) percentage per capita real GDP growth rate differentials are a function of differential growth rates of economic freedom, differentials in the growth of the quality of government regulation, and differentials in the growth rate of the burden of government taxation. A number of estimates are provided to demonstrate the resiliency and consistency of the findings of the basic model.

\section{2.- The Basic Framework: An Eclectic Model}

In this study, per capita real income is measured by the per capita real GDP level in each of the OECD nations over the four-year study period from 2003 through 2006. The value of per capita real GDP (income) is made comparable across nations by $P P P$ (purchasing-power-parity) adjustments. With $R P C Y$ being the $P P P$ adjusted level of per capita real GDP, the percentage increase in per capita real GDP, i.e, the percentage increase in $R P C Y$, is an economic variable that parallels, in principle, the focus of most of the more recent related studies on macroeconomic growth (Cebula, 2011; Goldsmith, 1995; Ali, 1997; Norton, 1998; Dawson, 1998, 2003; Cole, 2003; Hall, 2013; Hall, Sobel, and Crowley, 2010; Bennett and Vedder, 2013).

\footnotetext{
${ }^{2}$ Each nation during this time frame can be regarded either as a nation per se or as a de facto "economic region" within the OECD.
} 
Given the emphasis in this study on the role of economic freedom in determining the growth rate of per capita real GDP (income) and hence international differentials thereof, the most fundamental hypothesis of this study is that the percentage increase in per capita real GDP depends directly upon the percentage increase in economic freedom (FREEDOM) in each of its various studied forms, ceteris paribus. In addition, as explained above, the percentage increase in per capita real GDP is hypothesized to be an increasing function of the percentage increase in regulatory quality, $R E G Q U A L,{ }^{3}$ because high quality regulation interferes less with the efficient functioning of firms' decision-making processes in a market-based economy and contributes less to firms' production costs, ceteris paribus (Upadhyaya, Raymond, and Mixon, 1997; Clark, Boettke, and Stringham, 2008; Ugur, 2009; Yandle, 2013). Furthermore, the percentage increase in per capita real GDP is hypothesized to be a decreasing function of the percentage increase in the tax burden, expressed as a percent of GDP, TAXREVGDP,${ }^{4}$ because higher tax burdens reduce the growth rate of disposable income and thereby limit the growth rate of the ability to purchase new goods and services and hence reduce/restrict the rate of growth of economic activity, ceteris paribus.

The percentage rate of growth in per capita real GDP is also hypothesized to be a function of political stability as well as economic variables such as unemployment rates and $e x$ post real long term interest rates, $U R$ and $R L O N G I N T R$, respectively. Thus, the basic framework for analysis is initially expressed, as follows:

\footnotetext{
${ }^{3}$ The variable REGQUAL is adopted in lieu of the Heritage Foundation (2013) economic freedoms referred to as "business freedom" and "financial freedom."

${ }^{4}$ The variable TAXREVGDP is adopted in lieu of the Heritage Foundation (2013) economic freedom referred to as "fiscal freedom."
} 
Percentage increase in RPCYjt $=f($ percentage increase in FREEDOMnjt, percentage increase in TAXREVGDPjt, percentage increase in REGQUALjt, percentage increase in POLSTABjt, percentage increase in URjt, percentage increase in RLONGINTR)

where: RPCYjt is the level of the purchasing-power-parity adjusted per capita real income (GDP) in OECD nation $j$ in year $t$ and the percentage increase in $R P C Y j t$ is the percentage growth rate of the purchasing-power-parity adjusted per capita real GDP in OECD nation $j$ in year $t$; FREEDOMnjt refers to the value of the economic freedom measure (index) $n$ in nation $j$ in year $t$ ( $n=7$ in each of the estimations, as explained below);

TAXREVGDPjt is the ratio of all taxes in nation $j$ to the GDP level within nation $j$ in year $t$, expressed as percent;

REGQUALjt refers to the role played by government in the economy under the rubric of regulations and in fact is an index that measures the overall quality of those regulations in nation $j$ in year $t$;

POLSTABjt is an index that measures the degree of political stability in each nation/region $j$ in year $t$;

$U R j t$ is the unemployment rate and long term interest rate, in nation $j$ in year $t$; and RLONGINTRjt is the ex post real long term rate of interest in nation $j$ in year $t .^{5}$

\section{3. - Economic Freedom, Tax Burden, and Regulatory Quality}

This study considers the economic freedom indices developed by The Heritage Foundation (2013). Based on the central hypothesis investigated in this study, as stated above, as well as a

\footnotetext{
${ }^{5}$ Although a dummy variable for G8 nations is also included in certain estimations as a control variable.
} 
body of literature using earlier data, the growth rate of per capita real GDP is expected to be an increasing function of these indices of economic freedoms, ceteris paribus.

Arguably, the present study extends the literature on economic growth and economic freedom in a number of ways. To begin with, this study differs with most prior studies by focusing on OECD nations. In addition, it estimates a balanced four-year (2003 through 2006) panel dataset by fixed-effects. Furthermore, the present study constructs an overall average measure of economic freedom which expressly discards three of the ten Heritage Foundation (2013) economic freedoms, namely, fiscal freedom, business freedom, and financial freedom, primarily because of the multi-collinearity problems their presence creates and partly to replace them with arguably better variables to measure what the fiscal freedom, business freedom, and financial freedoms seek to measure, namely, by two separate variables: the ratio of all taxes to $G D P$ (expressed as a percent) and a direct measure of regulatory quality, the principal component of both financial freedom and business freedom. These substitutions are further explained later on in this section of the study. Finally, the present analysis provides a number of de facto economic control variables and a de facto political control variable. ${ }^{6}$

Given this context, we first identify freedom from excessive government size, or simply government size freedom (Heritage Foundation, 2013), an index that reflects the degree of freedom in an economy from the burden of excessive government in terms of expenditures (i.e., freedom from government on the expenditure side). Government outlays compete with private agents and interfere with natural market processes, prices, and interest rates by over-stimulating demand and diverting resources through "crowding out" effects, with government deficits

\footnotetext{
${ }^{6}$ Included in all of the estimates is a non-linear trend variable, and in two of the estimates there is a dummy/binary variable for G8 nations.
} 
typically being the financing vehicle leading to reduced economic growth (Carlson and Spencer, 1975; Cebula, 1978; Abrams and Schmitz, 1978). This economic freedom is labeled HECFR1.

The trade freedom index reflects the openness of an economic system to imports of goods and services from other nations and the ability of citizens to interact freely as buyers and sellers in the global marketplace. Government hindrance of the free flow of such commerce (through taxation of imports and/or exports, bans, quotas, and so forth) has a negative impact on the ability of individuals and firms to pursue their economic goals (Heritage Foundation, 2013). This economic freedom is denoted as HECFR2

A free citizenry requires a steady and reliable currency as a medium of exchange and as a store of value. The monetary freedom index is an indicator of stable currency and marketdetermined prices. A high degree of monetary freedom is characterized by an independent central bank, policies promoting low inflation, and the absence of price controls (Heritage Foundation, 2013). This economic freedom is referred to here as HECFR3.

The investment freedom index is greater in a nation with (1) fewer restrictions on foreign investment, (2) fewer restrictions that tend to limit capital inflows and outflows, and (3) fewer restrictions that hinder the ability of capital to flow to its best and most efficient use. Such restrictions interfere with the freedom of investors and firms seeking capital (Heritage Foundation, 2013). This economic freedom is referred to here as HECFR4.

Secure property rights provide citizens the confidence to engage in entrepreneurial activities, including commercial activities, saving, investing, and risk taking. The ability to accumulate private property is a primary motivation, if not the primary motivation, for participation in a market economy; a "rule of law" that effectively protects property rights is critical to an efficient free market economy. The greater the protections afforded to property 
rights under the rule of law, the greater the property rights freedom index (Heritage Foundation, 2013). This economic freedom is referred to here as HECFR5.

Political corruption by public officials manifests itself in many forms, including bribery, extortion, embezzlement, and graft, and it enables certain public officials to steal or otherwise profit illegitimately from public funds or the abuse of political power. Political corruption interferes with market efficiency. The freedom from corruption index indicates the degree to which an economy is free from such forms of corruption (Heritage Foundation, 2013). This economic freedom is labeled as HECFR6.

The labor freedom index is a composite index that reflects freedom from government wage and price controls and measures the ability of both workers and firms to interact freely without restrictions imposed by government. The greater the degree of labor freedom in an economy, the more efficient and productive is that economy (Heritage Foundation, 2013; Nissan and Niroomand, 2008). This economic freedom is referred to here as HECFR7.

The fiscal freedom index (Heritage Foundation, 2013) reflects the freedom of individuals and firms to keep and control their income and wealth for their own use/benefit. Fiscal freedom is a measure of freedom from the burden of government (from the revenue side): the lower this burden, the higher the value of the fiscal freedom index. Technically, fiscal freedom includes freedom from the tax burden, in terms of both the top income tax rate (on corporations and individuals, taken separately) and the overall amount of tax revenue as a percentage of a nation's GDP. The underlying premise is that higher taxation not only interferes with the ability of individuals and businesses to pursue their goals in the marketplace, it may also reduce the incentive to work, save, invest, or take risk. This economic freedom is labeled as HECFR8. 
Nearly all nations impose some form of supervision/oversight on banking institutions and the providers of other financial services, including markets for equities. The financial freedom index is an indicator of the degree to which the financial sector of the economy is free from excessive banking and financial regulation (Heritage Foundation, 2013). This economic freedom is labeled HECFR9.

The business freedom index reflects the individual's right and ability to freely conduct entrepreneurial activities (i.e., to create, to operate and thereby to make economic, financial, and management decisions, and to close an enterprise without government interference). It is argued that burdensome, redundant regulations are the most common barriers to the free conduct of entrepreneurial endeavors, and indeed are a de facto form of taxation that makes it difficult for entrepreneurs to produce goods and services (Heritage Foundation, 2013). This economic freedom is labeled HECFR10.

Of the ten economic freedoms measured above, three, HECFR8, HEFFR9, and HECFR10, are of special interest here in terms of whether there is a reasonable alternative way in which to capture their essential significance but perhaps in either a more direct fashion or in a technically less problematic fashion, i.e., one that avoids multi-collinearity with one or more other economic freedom measures. In particular, to measure the overall level of economic freedom using the Heritage Foundation (2013) indices of economic freedom and simultaneously to address the fact that, technically, these three specific economic freedoms create multicollinearity problems and may have other limitations, we define, with these three notable exceptions (fiscal freedom, HECFR8, financial freedom, HECFR9, and business freedom, 
HECFR10) the overall economic freedom measure, FREEDOMjt, as the average of the economic freedoms described above, where $n$ denotes the $n$th economic freedom: ${ }^{7}$

$$
\text { FREEDOMjt }=\stackrel{7}{\sum_{n=1} H E C F R n j t / 7, j=1, \ldots, 29 \text { for } t=2003, \ldots, 2006}
$$

The principal reason for defining the overall freedom index without fiscal freedom (HECFR8) included is that HECFR8 is highly correlated $(r=0.767)$ with government size freedom, HECFR1, and therefore introduces a multi-collinearity problem. In addition, however, it is noteworthy that the HECFR 8 index is constructed in part with an arguably excessive focus on just the top corporate and personal income tax brackets so that it may potentially fail to provide a systematic and purely objective inclusion of the remainder of the corporate and personal income tax structures, be they imposed by central governments or sub-central government entities. In point of fact, there are also numerous other tax forms besides income taxation that arguably must be systematically considered when quantifying fiscal freedom. Accordingly, HECFR 8 is replaced with a simple measure of the overall tax burden in each of the OECD nations, TAXREVGDPjt. This substitute for fiscal freedom has two advantages over HECFR8: simplicity and comprehensiveness on the one hand, i.e., it is computed as simply the sum of all taxes in nation $j$ in year $t$ expressed as a percent of GDP, and on the other hand, it is not highly correlated with HECFRI ( $r=0.392)$. In the spirit of $H E C F R 8$, it is of course expected that real per capita GDP growth is a decreasing function of TAXREVGDPjt, ceteris paribus (Clark and Lawson, 2008; Cebula, 2011; Yandle, 2013), i.e., the greater the percentage rate of increase in TAXREVGDPjt, the lower the percentage rate of increase in per capita real GDP.

\footnotetext{
${ }^{7}$ This problem of multi-collinearity is actually suggested by the Heritage Foundation (2013, pp. 15-16),
} 
A fundamental reason for defining the overall freedom index with financial freedom (HECHR9) and business freedom (HECFR10) excluded is the simple fact that these economic freedom measures, whose principal component is government regulation in a variety of forms, also are highly correlated ( $r=0.646$ and $\mathrm{r}=0.632$, respectively) with investment freedom. That said, in order to reflect the role of government in the economic environment as a regulator per $s e$, this study adopts in place of HECFR9 and HECFR10 the variable described as "regulatory quality" by the World Bank Institute (2012, p. 1). This regulatory quality variable, expressed by the symbol REGQUALjt in the present study, is an index that reflects "...the ability of the government to provide sound policies and regulations that enable and promote private sector development" (World Bank Institute, 2012, p. 9). It is hypothesized that the greater/the higher the degree of regulatory quality in nation $j$ in year $t, R E G Q U A L j t$, i.e., the greater the percentage rate of increase of REGQUALjt, the greater the percentage rate of growth of economic activity and hence the greater the growth rate of per capita real GDP in nation $j$ in year $t$, ceteris paribus (Upadhyaya, Raymond, and Mixon, 1997; Ugur, 2009; Yandle, 2013, esp. pp. 5-9). ${ }^{8}$ Finally, the percentage rate of increase in real GDP, in the spirit of the existing literature on growth and economic freedom, is hypothesized to be an increasing function of the percentage rate of increase of the seven-pronged economic freedom variable FREEDOMjt, ceteris paribus.

\section{4.- Economic and Political Stability Control Variables and a Trend Variable}

In addition to the hypothesized impacts of economic freedom, taxes as a percent of GDP, and regulatory quality on real per capita GDP growth, this study initially includes two explicitly economic "control" variables, a political control variable, and a trend variable. The explicitly

\footnotetext{
${ }^{8}$ The potential economic significance of regulation (good quality) is considered in a diverse literature (Mixon, 1994, 1995; Yandle, 2013; Clark, Boettke and Stringham, 2008).
} 
economic control variables are the average percentage unemployment rate in country $j$ in year $t$ (URjt) and the average ex post real long term rate of interest in country $j$ in year $t$ (RLONGINTjt). As noted in Cecchetti (2006, p. 567), the unemployment rate variable controls for the expected negative influence of higher unemployment rates on per capita real income growth: the greater the percentage rate of increase of the labor force that is unemployed, the lower the percentage rate of increase in per capita real GDP, ceteris paribus. Next, as observed by Cecchetti (2006, p. $555)$, " “..the economic decisions of households to save and of firms to invest depend on the real interest rate..." Similarly, Mishkin (2013, p. 609) observes that the traditional view is that "...a fall in real interest rates...lowers the cost of borrowing, causing a rise in investment spending... and consumer durable expenditure..." According to the "conventional wisdom" then, ${ }^{9}$ the higher the ex post real long term rate of interest, the lower the present value of investment for firms and hence the lower the rate of investment in new plant and equipment, ceteris paribus. Moreover, consumption, particularly consumption of durable goods (including housing), is likely also a decreasing function of the ex post real long term rate of interest, ceteris paribus. Thus, the higher the percentage rate of increase in the ex post real long term interest rate, the lower the percentage rate of increase in economic activity and hence the lower the percentage growth rate of per capita real GDP.

We also introduce a political control variable for each nation, POLSTABjt, which is an index of political stability and the absence of violence in those nations. It is hypothesized that economic prosperity and economic growth for an economy as a whole should be an increasing function of political stability, which by its very nature, promotes orderly or lower risk decision making and greater efficiency for markets to function in an economic system (World Bank

\footnotetext{
${ }^{9}$ See also Jansen, Delorme, and Ekelund (1994, esp. pp. 268-269), Taylor, 1999, p. 95), and Allison (2013, pp. 26270).
} 
Institute, 2012, p. 9; Clark and Lawson, 2006; Cebula, 2011) and thereby should act, ceteris paribus, to elevate per capita real GDP growth, i.e., the greater the rate of increase in the index of political stability, the greater the rate of increase in per capita real GDP. Finally, the nonlinear trend variable, $T R$, is included to account for trending of variables/data over the four-year study period. Interestingly, use of a linear trend variable in place of the non-linear trend variable does not alter the conclusions in any instance.

For the interested reader, it is observed that the variables reflecting "regulatory quality" and "political stability" are in fact quite different. The variable used to measure regulatory quality, REGQUAL, reflects the ability of the government of a nation both to formulate and execute/implement sound, rational, and objective policies and regulations that not only permit but also promote private sector development and efficiency (World Bank, 2012, p. 5). By contrast, the variable used to reflect political stability, POLSTAB, actually measures the perceived likelihood that the government of a nation is vulnerable to being destabilized or even overthrown by either constitutional or violent means, with the latter including politicallymotivated violence and terrorism (World Bank Institute, 2012, p. 9). From a different perspective, to illustrate how statistically unrelated these two variables are, the zero-order correlation coefficient between them is nearly 0 , i.e., $r=0.068$.

\section{5.- Fixed-Effects Estimation Results}

Predicated upon the eclectic framework of determinants of the percentage increase in per capita real GDP described above, the following model is to be estimated initially:

$$
\begin{aligned}
& \text { Log RPCYjt }=a+b \log F R E E D O M j t+c \log R E G Q U A L j t+d \log T A X R E V G D P j t \\
& +e \log \text { POLSTABjt }+f \log U R j t+g \log R L O N G I N T R j t+h T R
\end{aligned}
$$

where it is hypothesized that: 


$$
b>0, c>0, d<0, e>0, f<0, g<0
$$

Data for each of the seven economic freedom variables/indices (HECFRnjt) considered here, the average of which is the variable FREEDOMjt, were obtained from the Heritage Foundation (2013); data for the PPP (purchasing-power-parity) adjusted real per capita GDP variable $(R P C Y)$ were obtained from the International Monetary Fund (2013); data for the variables TAXREVGDP, UR, and RLONGINTR (more specifically, the percentage nominal average annual long term interest rate yield minus the percentage annual inflation rate) were obtained from the OECD (2013); and data for the governance indices for regulatory quality (REGQUAL) and political stability (POLSTAB) were obtained from the World Bank Institute (2012). Finally, TR is a non-linear trend variable. Descriptive statistics for each of the non-trend variables in the analysis are provided in Table 1.

Equation (3), which is expressed in log-log form, was estimated by PLS (panel least squares), first using the random effects model and then using the fixed-effects model. In this log-log specification, a Hausman specification test (Hausman, 1978) was performed, and it generated a $t$-statistic with a $p=.0412$, so that the study adopts the fixed-effects model. Similar outcomes, i.e., $p<.05$, were obtained for all of the models estimated in this study, so that all of the results provided in the present study are fixed-effects estimates.

Equation (3) is estimated adopting the White (1980) cross-section correction. ${ }^{10}$ These results are provided in column (a) of Table 2, where all six of the estimated elasticity values for the non-trend variables exhibit the expected signs. Of these six elasticity values, four are statistically significant at the $1 \%$ level, one is statistically significant at the $5 \%$ level, and one is

\footnotetext{
${ }^{10} \mathrm{All}$ of the estimations in this study adopt the White (1980) cross-section heteroskedasticity correction.
} 
statistically significant at the $10 \%$ level. In addition, the trend variable is negative and statistically significant at the $5 \%$ level.

Thus, as hypothesized, these fixed-effects results reveal that the percentage growth rate in per capita real GDP among OECD nations during the study period is an increasing function of economic freedom and regulatory quality and a decreasing function of the tax burden (as a percent of GDP), as well as the unemployment rate and the ex post real long term interest rate. Furthermore, there is modest evidence of a positive impact of political stability on that real GDP growth rate. Thus, for example, a one percent increase in the Heritage Foundation overall economic freedom index, as computed in equation (2), would elevate the per capita real GDP growth rate by $1.02 \%$. Therefore, a rise in this Heritage Foundation (2013) measure of economic freedom index of $10 \%$ presumably would be expected to elevate the per capita real GDP growth rate by approximately $10.2 \%$. In addition, a rise in the REGQUAL index of one percent would raise the per capita real GDP growth rate by $1.035 \%$, whereas a rise of one percent in the percentage ratio of taxes to GDP would reduce the per capita real GDP growth rate by $0.404 \%$. Furthermore, a one percent rise in the unemployment rate or the ex post real long term interest rate would reduce the per capita real GDP growth rate by $0.167 \%$ or $0.38 \%$, respectively. Finally, there is weak/modest evidence that a one percent rise in the political stability index would raise the real per capita GDP growth rate by $0.176 \%$. The coefficient of determination values (the $R^{2}$ and adjusted $R^{2}$ ) imply that the model explains three-fourths or more of the variation in the dependent variable, the percentage per capita real GDP growth rate. Furthermore, for the interested reader, Table 3 provides the correlation matrix among the explanatory variables in equation (3); clearly, multi-collinearity is not a serious problem. 
The estimate in column (a) of Table 2 is predicated upon a composite index of seven Heritage Foundation (2013) measures of economic freedom as well as an index of regulatory quality and the burden of government taxation; the estimate also includes an index of political stability and two explicitly economic variables, one reflecting unemployment and the other the long term cost of borrowing. As a modest test of the resiliency and consistency of the conclusions for the per capita real GDP growth rate effects of economic freedom, as well as the regulatory quality and tax-burden variables, which are the focus explanatory variables in this study, the next estimation provided in Table 2 of this study offers alternative fixed-effects results of a parallel model. The difference between the specification of this alternative model and that considered in column (a) of Table 2 is the adoption of a de facto economic control dummy variable, G8DUMMY, which assumes a value of 1 for a G8 nation and a value of 0 otherwise. This variable is included in the analysis to control for the fact that G8 nations tend to have educational, technology, infrastructure, and other advantages as compared with many if not most non-G8 nations and the fact that these advantages tend to result in labor higher productivity and labor productivity growth and hence higher percentage growth rates in per capita real GDP, ceteris paribus (Nissan and Niroomand, 2010).

The log-log estimations of the basic model with the G8DUMMY included can be found in column (b) of Table 2, where all seven of the estimated non-trend elasticity values exhibit the expected signs, with four statistically significant at the $1 \%$ level and three statistically significant at the 5\% level. Thus, the percentage per capita real GDP growth rate is found to have been an increasing function of economic freedom, regulatory quality, and political stability. It also is positively impacted by having G8 status, as hypothesized. The percentage per capita real GDP growth rate is also a decreasing function of a higher tax burden, the unemployment rate, and the 
ex post real long term interest rate. More specifically, a one percent increase in the Heritage Foundation overall economic freedom index, as computed in equation (2), would elevate the per capita real GDP growth rate by $1.093 \%$. In addition, a rise in the REGQUAL index of one percent would raise the per capita real GDP growth rate by $1.03 \%$, whereas a rise of one percent in the percentage ratio of taxes to GDP would reduce the per capita real GDP growth rate by $0.36 \%$. Furthermore, a one percent rise in the unemployment rate or the ex post real long term interest rate would reduce the per capita real GDP growth rate by $0.17 \%$ or $0.33 \%$, respectively, whereas a one percent rise in the political stability index would raise the real per capita GDP growth rate by $0.185 \%$. Finally, there are the results for the G8DUMMY variable. According to column (b), being a G8 nation implies a roughly $0.159 \%$ higher percentage growth rate of per capita real GDP.

Additionally, the non-linear trend variable is statistically significant (and negative) at the $5 \%$ level, attesting once again to the propriety of its inclusion in the model. The coefficients of determination $\left(R^{2}=0.79\right.$; adjusted $\left.R^{2}=0.77\right)$ imply the model explains more than three-fourths of the variation in the dependent variable. Clearly, among other things, this estimate provides strong support for the three central hypotheses being investigated in this study.

To further test the consistency and resiliency of the model, in column (c) of Table 2, we introduce another variable, in particular, the one-year lag of the dependent variable. In this estimation, seven of the eight estimated non-trend elasticity values exhibit the expected signs, with four statistically significant at the $1 \%$ level and three statistically significant at the $5 \%$ level; meanwhile, the trend variable is once again negative and statistically significant at the 5\% level. The coefficients of determination $\left(R^{2}=0.79\right.$; adjusted $\left.R^{2}=0.77\right)$ imply the model once again explains more than three-fourths of the variation in the dependent variable. 
Clearly, among other things, this estimate provides support for the three central hypotheses being investigated in this study. In particular, from these results, we infer that the percentage increase in the per capita real GDP growth rate is an increasing function of the percentage increase in economic freedom, regulatory quality, and political stability, as well as by having G8 status, once again, as hypothesized. The percentage increase in the per capita real GDP growth rate is also a decreasing function of the percentage increase in the tax burden, the unemployment rate, and the ex post real long term interest rate. Additionally, the non-linear trend variable is statistically significant (and negative) at the $5 \%$ level, attesting once again to the propriety of its inclusion in the model. Finally, although the lagged dependent variable was not statistically significant at even the $10 \%$ level, its inclusion in the model did not alter these basic implications of the model.

As for the findings in column (c) of Table 2, a one percent increase in the Heritage Foundation overall economic freedom index, as computed in equation (2), would elevate the percentage increase in per capita real GDP by $1.355 \%$. In addition, a rise in the REGQUAL index of one percent would raise the per capita real GDP growth rate by $1.01 \%$, whereas a rise of one percent in the percentage ratio of taxes to GDP would reduce the per capita real GDP growth rate by $0.384 \%$. Furthermore, a one percent rise in the unemployment rate or the ex post real long term interest rate would reduce the per capita real GDP growth rate by $0.172 \%$ or $0.35 \%$, respectively. There also is evidence that a one percent rise in the political stability index would raise the real per capita GDP growth rate by $0.19 \%$. Finally, according to column (c) being a G8 nation implies a roughly $0.155 \%$ higher percentage growth rate of per capita real GDP. 


\section{6.- Additional Results: Dynamic Fixed Effects PLS Estimates}

As a simple test of the robustness of the results provided in Table 2, we re-estimate the basic system in somewhat different terms. In particular, rather than defining economic growth in terms of the percentage change in per capita real GDP, we define economic growth, as well as all of the explanatory variables, simply in change form. For example, the variable for economic growth becomes the change in $P P P$-adjusted per capita real GDP $(\triangle R P C Y j t)$. Thus, the model consists of the following, in addition to $\triangle R P C Y j t$ : the freedom variable becomes simply the change in the economic freedom index ( $\triangle$ FREEDOMjt); the regulation variable is simply the change in the value of the regulation index ( $\triangle R E G Q U A L j t)$; the tax variable becomes the change in the ratio of the total tax burden to GDP ( $\triangle T A X R E V G D P j t)$; and so forth, so that the new version of the basic model becomes the following dynamic fixed effects model:

$$
\begin{aligned}
& \triangle R P C Y j t=a^{\prime}+b^{\prime} \Delta F R E E D O M j t+c^{\prime} \triangle R E G Q U A L j t+d^{\prime} \Delta T A X R E V G D P j t \\
& +e^{\prime} \triangle P O L S T A B j t+f^{\prime} \Delta U R j t+g^{\prime} \Delta R L O N G I N T R j t+h^{\prime} T R
\end{aligned}
$$

where it is expected that:

$$
\mathrm{b}^{\prime}>0, \mathrm{c}^{\prime}>0, \text { d' }^{\prime}<0, \text { e' }^{\prime} \text { o, f' }<0, \text { g' }^{\prime}<0
$$

Estimates of equation (5) and variations upon equation (5) that parallel the estimations shown in Table 2 are provided in Table 4. For the most part, these new results are qualitatively very similar to their counterparts in Table 2; indeed, except for the cases of the unemployment rate and the lagged dependent variable ( $\triangle R P C Y_{t-1}$, found only in column (c) of Table 4), the results shown in Table 4 provide results that are qualitatively entirely compatible with those in Table 2. Hence, from the perspective of the objectives of this study, we obtain additional results that, among other things, provide further support for the three central hypotheses being investigated in this study. In particular, from these results, we infer that the increase in the per capita real GDP growth rate is an increasing function of the percentage increase in economic 
freedom and regulatory quality while being a decreasing function of the percentage increase in the ratio of the tax burden to the GDP level.

\section{7.- Summary}

The fixed-effects estimations in this study all provide strong support for the three central hypotheses considered here, namely: (1) per capita real GDP growth depends directly upon the overall economic freedom index (FREEDOM), which in this study consists of seven of the ten Heritage Foundation (2013) economic freedom indices, presumably at least in part due to the ability of increased economic freedom to elevate the growth/rate of economic activity through incentives to work, invest, save, hire/dismiss, make market-based business decisions, and take risk and engage in risk-reward economic behaviors in a market-based economy; (2) per capita real GDP growth depends directly on the index of regulatory quality, REGQUAL, (World Bank Institute, 2012) because high quality regulation interferes less with the efficient functioning of firms' decision-making processes in a market-based economy and contributes less to firms' production costs, and (3) per capita real GDP growth is a decreasing function of the tax burden, expressed as a percent of GDP, TAXREVGDP, (OECD, 2013) because higher tax burdens reduce the growth rate of disposable income and thereby limit the growth rate of the ability to purchase new goods and services and hence reduce/restrict the rate of growth of economic activity.

Naturally, these conclusions are at least somewhat preliminary. More work, alternative specifications involving additional or different variables (including different control variables) could yield broader, if not more compelling, insights. In addition, perhaps the adoption/study of alternative datasets, such as that by Gwartney, Lawson and Hall (2012), and/or additional years 
needs to be considered and estimated. ${ }^{11}$ Thus, although these results appear to suggest a strong relationship between the percentage rate of growth of per capita real GDP on the one hand and economic freedom, regulatory quality, and the overall tax burden on the other hand, this topic requires further scrutiny and formal investigation.

\section{REFERENCES}

Abrams, B.A., and Schmitz, M.D. (1978). "The 'Crowding Out' Effect of Government Transfers on Private Charitable Contributions," Public Choice, 33 (1): 29-39.

Ali, A. (1997). "Economic Freedom, Democracy and Growth," Journal of Private Enterprise, 13 (1): $1-20$.

Ali, A., and Crain, W.M. (2001). "Political Regimes, Economic Freedom, Institutions and Growth," Journal of Public Finance and Public Choice, 19 (1): 3-22.

Allison, J.A. (2013). The Financial Crisis and the Free Market Cure. New York: McGraw-Hill.

Bennett, D.L. and Vedder, R.K. (2013). "A Dynamic Analysis of Economic Freedom and Income Inequality in the 50 U.S. States: Evidence of a Parabolic Relationship," Journal of Regional Analysis and Policy, 43 (1): 42-55.

Carlson, K.M., and Spencer, R. W. (1975). "Crowding Out and Its Critics," Federal Reserve Bank of St. Louis Review, 60 (12): 1-19.

Cebula, R.J. (1978). "An Empirical Analysis of the Crowding Out of Fiscal Policy in the United States and Canada," Kyklos, 31 (3): 424-436.

Cebula, R.J. (2011). "Economic Growth, Ten Forms of Economic Freedom, and Political Stability," Journal of Private Enterprise, 26 (2): 61-82.

Cecchetti, S.G. (2006). Money, Banking, and Financial Markets. New York: McGraw-Hill.

Clark, J.R., and Lawson, R.A. (2008). "The Impact of Economic Growth, Tax Policy, and Economic Freedom on Income Inequality," Journal of Private Enterprise, 24 (1): 23-31.

Clark, J.R., Boettke, P.J., and Stringham, E. (2008). "Are Regulations the Answer for Emerging Stock Markets? Evidence from the Czech Republic and Poland," Quarterly Review of Economics and Finance, 48 (3): 541-566.

\footnotetext{
${ }^{11}$ Use of this dataset in place of the Heritage Foundation (2013) dataset yields the same conclusions; these findings are available upon request.
} 
Cole, J.H. (2003). "The Contribution of Economic Freedom to World Economic Growth," 198099, Cato Journal, 23 (2): 189-198.

Dawson, J.W. (2003). “Causality in the Freedom-Growth Relationship,” European Journal of Political Economy, 19 (3): 479-495.

Dawson, J.W. 1998. "Institutions, Investment, and Growth: New Cross-Country and Panel Data Evidence," Economic Inquiry, 36 (4): 603-619.

De Haan, J., and Sturm, J. (2000). “On the Relationship between Economic Freedom and Economic Growth," European Journal of Political Economy, 16 (2): 215-241.

Goldsmith, A.A. (1995). "Democracy, Property Rights and Economic Growth," The Journal of Development Studies, 32 (2): 157-174.

Grubel, H.G. (1997). "Economic Freedom and Human Welfare: Some Empirical Findings," The Cato Journal, 18 (2): 287-304.

Gwartney, J., Holcombe, R., and Lawson, R.A. (2006). "Institutions and the Impact of Investment on Growth," Kyklos, 59 (2): 255-276.

Gwartney, J., Lawson, R.A., and Hall, J. (2012). "Economic Freedom of the World: 2012 Report." http://www.freetheworld.com/datasets_efw.html

Hall, J. (2013). "Economic Freedom and Regional Economics," Journal of Regional Analysis and Policy, 43 (1): 1-3.

Hall, J., Sobel, R., and Crowley, G. (2010). "Institutions, Capital, and Growth," Southern Economic Journal, 77 (2): 385-405.

Hausman, J.A. (1978). "Specification Tests in Econometrics," Econometrica, 46 (6): 1,2731,291 .

Heckelman, J.C. (2000). "Economic Freedom and Economic Growth: A Short-Run Causal Relationship," Journal of Applied Economics, 3 (1): 71-91.

Heckelman, J.C., and Stroup, M.D. (2000). "Which Economic Freedoms Contribute to Economic Growth?” Kyklos, 53 (4): 527-544.

Heritage Foundation. (2013). "Economic Freedom Indices: Explore the Data." At http://www.heritage.org/Index/Explore.aspx

International Monetary Fund. (2013). "Data and Statistics.” at http://www.imf.org/external

Islam, S. (1996). "Economic Freedom, Per Capita Income, and Economic Growth," Applied Economics Letters, 3 (10): 595-597. 
Jansen, D.W., DeLorme, C.D., and Ekelund, R.B. (1994). Intermediate Macroeconomics. Minneapolis/St. Paul, MN: West Publishing Co.

Mishkin, F.S. (2013). The Economics of Money, Banking, and Financial Markets. New York; Pearson.

Mixon, F.G., Jr. (1994). "What Can Regulators Regulate? The Case of the Urban Heat Island Phenomenon," American Journal of Economics and Sociology 53 (3): 403-414.

Mixon, F.G., Jr. (1995). "Public Choice and the EPA: Empirical Evidence on Carbon Emissions Violations," Public Choice 83 (1):127-137.

Nissan, E., and Niroomand, F. (2010). "Distribution of Income and Expenditures across Nations," Journal of Economics and Finance, 34 (2): 173-186.

Nissan, E., and Niroomand, F. (2008). "Linking Labor Productivity to Economic Freedom," The American Economist, 52 (2): 42-53.

Norton, S.W. (1998). "Poverty, Property Rights, and Human Well-Being: A Cross-National Study," Cato Journal, 18 (2): 233-246.

Organization for Economic Co-operation and Development (OECD). (2013). "OECD Economic Surveys: Statistics from A to Z." http://www.oecd.org/statistics/.

Taylor, M. (1999). "Real Interest Rates and Macroeconomic Activity," Oxford Review of Economic Policy, 15 (2): 95-113.

Ugur, M. (2009). "Regulatory Quality and Performance in EU Network Industries: Evidence on Telecommunications, Gas and Electricity," Journal of Public Policy 29 (3): 347-370.

Upadhyaya, K.P., J.E. Raymond and F.G. Mixon, Jr. (1997). “The Economic Theory of Regulation Versus Alternative Theories for the Electric Utilities Industry: A Simultaneous Probit Model," Resource and Energy Economics 19 (2): 191-202.

White, H. (1980). "A Heteroskedasticity-Consistent Covariance Matrix and a Direct Test for Heteroskedasticity,” Econometrica, 48 (4): 817-838.

Wiseman, T., and Young, A. (2011). "Economic Freedom, Entrepreneurship, and Income Levels: Some U.S. State-level Empirics," at http://dx.doi.org/10.2139/ssrn.1817846

World Bank Institute. (2012). Governance Indicators. At http://www.govindicators.org/

Yandle, B. (2013). The Economic Situation. Clemson, SC: Clemson University. 
Table 1. Descriptive Statistics

$\begin{array}{lll}\text { Variable } & \text { Mean } & \text { Standard Deviation } \\ \text { RPCY } & 26,969 & 11,636 \\ \text { FREEDOM } & 69.98 & 7.788 \\ \text { REGQUAL } & 1.302 & 0.437 \\ \text { TAXREVGDP } & 35.92 & 7.198 \\ \text { POLSTAB } & 0.77 & 0.53 \\ \text { UR } & 6.66 & 3.27 \\ \text { RLONGINTR } & 3.54 & 2.23 \\ \text { G8DUMMY } & 0.241 & 0.43\end{array}$


Table 2. Initial Fixed-Effects Estimates

Dependent Variable: $\log R P C Y$

\begin{tabular}{|c|c|c|c|}
\hline & (a) & (b) & (c) \\
\hline Log FREEDOM & $\begin{array}{l}1.02 * * * \\
(2.78)\end{array}$ & $\begin{array}{l}1.093 * * * \\
(3.07)\end{array}$ & $\begin{array}{l}1.355^{* * * *} \\
(2.59)\end{array}$ \\
\hline Log REGQUAL & $\begin{array}{l}1.035^{* * * *} \\
(7.37)\end{array}$ & $\begin{array}{l}1.03 * * * \\
(7.29)\end{array}$ & $\begin{array}{l}1.01 * * * \\
(6.39)\end{array}$ \\
\hline Log TAXREVGDP & $\begin{array}{l}-0.404 * * * \\
(-2.58)\end{array}$ & $\begin{array}{l}-0.36 * * \\
(-2.30)\end{array}$ & $\begin{array}{l}-0.384 * * \\
(-2.47)\end{array}$ \\
\hline Log POLSTAB & $\begin{array}{l}0.176^{*} \\
(1.68)\end{array}$ & $\begin{array}{l}0.185^{* * *} \\
(1.98)\end{array}$ & $\begin{array}{l}0.19 * * \\
(2.00)\end{array}$ \\
\hline $\log U R$ & $\begin{array}{l}-0.167 * * \\
(-2.32)\end{array}$ & $\begin{array}{l}-0.17 * * \\
(-2.41)\end{array}$ & $\begin{array}{l}-0.172 * * \\
(-2.44)\end{array}$ \\
\hline Log RLONGINTR & $\begin{array}{l}-0.38 * * * \\
(-3.37)\end{array}$ & $\begin{array}{l}-0.33 * * * \\
(-2.83)\end{array}$ & $\begin{array}{l}-0.347 * * * \\
(-3.12)\end{array}$ \\
\hline G8DUMMY & ------- & $\begin{array}{l}0.159 * * * \\
(3.47)\end{array}$ & $\begin{array}{l}0.155^{* * * *} \\
(3.52)\end{array}$ \\
\hline $\begin{array}{l}\log R P C Y_{t-1} \\
\text { (Lagged Dependent } \\
\text { Variable) }\end{array}$ & ------- & ------- & $\begin{array}{l}-0.078 \\
(-0.95)\end{array}$ \\
\hline$T R$ & $\begin{array}{l}-0.02 * * \\
(-2.45)\end{array}$ & $\begin{array}{l}-0.02 * * \\
(-2.27)\end{array}$ & $\begin{array}{l}-0.02 * * \\
(-2.36)\end{array}$ \\
\hline Constant & $\begin{array}{l}3.18^{*} \\
(1.66)\end{array}$ & $\begin{array}{l}2.55 \\
(1.36)\end{array}$ & $\begin{array}{l}2.43 \\
(1.31)\end{array}$ \\
\hline $\begin{array}{l}R^{2} \\
\operatorname{adj} R^{2}\end{array}$ & $\begin{array}{l}0.78 \\
0.76\end{array}$ & $\begin{array}{l}0.79 \\
0.77\end{array}$ & $\begin{array}{l}0.79 \\
0.77\end{array}$ \\
\hline
\end{tabular}

$* * *$ statistically significant at $1 \%$ level; $* *$ statistically significant at $5 \%$ level; *statistically significant at $10 \%$ level. 
Table 3. Correlation Matrix among Explanatory Variables in Basic Model

\section{FREEDOM REGQUAL TAXREVGDP POLSTAB UR RLONGINTR}

FREEDOM 1.000

REGQUAL $\quad-0.181 \quad 1.000$

$\begin{array}{lll}\text { TAXREVGDP }-0.168 & 0.453 \quad 1.000\end{array}$

$\begin{array}{lllll}\text { POLSTAB } & -0.498 & -0.054 & 0.179 & 1.000\end{array}$

$\begin{array}{llllll}U R & -0.488 & 0.072 & 0.088 & 0.205 & 1.000\end{array}$

$\begin{array}{lllllll}\text { RLONGINTR } & 0.198 & -0.439 & -0.325 & -0.115 & -0.233 & 1.000\end{array}$ 
Table 4. Additional Fixed-Effects Estimates

Dependent Variable: $\quad \triangle R P C Y$

\begin{tabular}{|c|c|c|c|}
\hline & (a) & (b) & (c) \\
\hline$\triangle F R E E D O M$ & $\begin{array}{l}704.1 * * * \\
(3.92)\end{array}$ & $\begin{array}{l}727.2 * * * \\
(4.23)\end{array}$ & $\begin{array}{l}928.2 * * * \\
(5.71)\end{array}$ \\
\hline$\triangle R E G Q U A L$ & $\begin{array}{l}545.01 * * * \\
(13.65)\end{array}$ & $\begin{array}{l}544.1 * * * \\
(14.22)\end{array}$ & $\begin{array}{l}435.2 * * * \\
(10.10)\end{array}$ \\
\hline$\triangle T A X R E V G D P$ & $\begin{array}{l}-356.3^{* *} \\
(-2.38)\end{array}$ & $\begin{array}{l}-395.6 * * * \\
(-2.75)\end{array}$ & $\begin{array}{l}-324.3^{* *} \\
(-2.47)\end{array}$ \\
\hline$\triangle P O L S T A B$ & $\begin{array}{l}147.31 * * * \\
(3.93)\end{array}$ & $\begin{array}{l}155.7 * * * \\
(4.32)\end{array}$ & $\begin{array}{l}127.5^{* * *} \\
(3.84)\end{array}$ \\
\hline$\Delta U R$ & $\begin{array}{l}-188.09 \\
(-0.55)\end{array}$ & $\begin{array}{l}-143.4 \\
(-0.44)\end{array}$ & $\begin{array}{l}-364.4 \\
(-1.23)\end{array}$ \\
\hline$\triangle R L O N G I N T R$ & $\begin{array}{l}-889.9 * * \\
(-2.08)\end{array}$ & $\begin{array}{l}-994.1 * * \\
(-2.41)\end{array}$ & $\begin{array}{l}-1,241.04 * * * \\
(-3.29)\end{array}$ \\
\hline G8DUMMY & ------- & $\begin{array}{l}6,800.8 * * * \\
(2.81)\end{array}$ & $\begin{array}{l}8,253 * * * \\
(3.73)\end{array}$ \\
\hline $\begin{array}{l}\triangle R P C Y_{t-1} \\
\text { (Lagged Dep. Var.) }\end{array}$ & ------- & ------- & $\begin{array}{l}-0.369 * * * \\
(-4.23)\end{array}$ \\
\hline$T R$ & $\begin{array}{l}-178.2 \\
(-0.58)\end{array}$ & $\begin{array}{l}-154.6 \\
(-0.52)\end{array}$ & $\begin{array}{l}-64.43 \\
(-0.24))\end{array}$ \\
\hline Constant & $\begin{array}{l}906.6 \\
(0.49)\end{array}$ & $\begin{array}{l}-823.4 \\
(-0.44)\end{array}$ & $\begin{array}{l}-1,607.1 \\
(-0.94)\end{array}$ \\
\hline $\begin{array}{l}R^{2} \\
\operatorname{adj}^{2}\end{array}$ & $\begin{array}{l}0.76 \\
0.74\end{array}$ & $\begin{array}{l}0.78 \\
0.76\end{array}$ & $\begin{array}{l}0.83 \\
0.80\end{array}$ \\
\hline
\end{tabular}

$* * *$ statistically significant at $1 \%$ level; $* *$ statistically significant at $5 \%$ level; *statistically significant at $10 \%$ level. 